\title{
ANALISIS LAPORAN SUMBER DAN PENGGUNAAN KAS PADA KUD TANI MAKMUR TAWANGMANGU KABUPATEN KARANGANYAR
}

\author{
RUKMINI \\ STIE AAS Surakarta \\ Email : rukminidra@yahoo.co.id
}

\begin{abstract}
ABSTRAK
Untuk mengetahui sebab-sebab terjadinya perubahan kas baik itu kenaikan atau penurunan kas setiap periodenya dapat dialakukan dengan analisis sumber dan penggunaan Kas. Obyek penelitian dilakukan pada KUD tani Makmur Tawangmangu Kabupaten Karanganyar. Sumber kas terbesar tahun 2013 berasal dari bertambahnya kewajiban jangka panjang yaitu berupa simpanan lain-lain. Penggunaan kas terbesar tahun 2013 digunakan untuk penyimpanan dana dalam bentuk Deposito sebesar Pada periode tahun 2013 terjadi kenaikan kas hal ini disebabkan karena pada tahun 2013 sumber kas lebih besar dari penggunaan kas .Adapun kenaikan kas tahun 2013 di koperasi berarti bahwa KUD Tani Makmur telah melaksanakan fungsi dan tujuannya dengan sebaik-baiknya untuk mewujudkan kesejahteraan pada anggota khususnya dan masyarakat pada umumnya.
\end{abstract}

Kata Kunci : Sumber Kas, Penggunaan Kas, Perubahan Kas

\section{PENDAHULUAN}

Koperasi Indonesia adalah organisasi rakyat yang berwatak social beranggotakan orang orang atau badan hukum yang berasaskan kekeluargaan. Adapun tujuan dari koperasi tersebut memajukan ekonomi masyarakat pada umumnya dan anggota pada khususnya.

Dalam setiap koperasi pasti sangat membutuhkan kas, karena kas mempunyai peranan yang penting sebagai sentral dalam menjaga kelancaran kegiatan perkoperasian. Kas digunakan untuk membiayai seluruh usaha dan kegiatan atau transaksi sehari hari di sebuah koperasi. Demikian juga yang terjadi di KUD Tani Makmur Tawangmangu. Jadi jumlah kas didalam koperasi harus cukup memadai. Oleh karenanya sangatlah pentin dalam menentukan jumlah kas yang tepat. Disamping itu di KUD Tani Makmur masih ada sedikit kendala yang terletak pada lemahnya penggunaan kas yang efektif. Oleh karena itu dirasakan sangat penting bagi koperasi untuk menganalisis kenaikan atau penurunan kas setiap periodenya.

Dengan menggunakan analisis sumber dan penggunaan kas maka akan diketahui sebab sebab terjadinya perubahan kas baik itu kenaikan atau penurunan kas setiap periodenya. Hal ini bisa dilakukan dengan cara menyajikan laporan keuangan perbandingan minimal 2 tahun berturut turut. Kemudian bisa disusun Laporan Sumber dan penggunaan Kas yang akan menunjukkan 
posisi Kas pada periode tertentu ( Munawir, 2010). Dengan demikian kas dalam koperasi harus selalu digunakan tepat sasaran dan dipantau dengan sebaik baiknya, mulai dari mana penerimaannya maupun penggunaannya. Dengan adanya analisa ini dapat pula digunakan sebagai dasar dalam menaksir kebutuhan kas dimasa yang akan datang atau dapat digunakan sebagai dasar perencanaan dalam menentukan sumber kas berasal dan penggunaan kas yang tepat.

Dari uraian diatas dapat dirumuskan Masalah sebagai berikut :

1. Berapa perubahan kas pada Koperasi Unit Desa Tani Makmur Tawangmangu pada periode 2012 dan 2013

2. Darimana sumber kas yang diperoleh Koperasi Unit Desa Tani Makmur Tawangmangu pada periode tahun 2012 tahun 2013

3. Untuk apa saja penggunaan kas pada Koperasi Unit Desa Tani Makmur Tawangmangu pada periode tahun 2012 tahun 2013

\section{KERANGKA PEMIKIRAN TEORITIS}

\section{A. Pengertian Kas}

1. Kas menurut pengertian Akuntansi adalah uang dan alat pembayaran lainnya yang dapat disamakan dengan uang ( Slamet Sugiri, 1997)

2. Kas adalah uang tunai baik uang kertas maupun uang logam yang dikeluarkan oleh negara maupun yang masih berlaku simpanan giro dan bentuk bentuk alat pembayaran lainnya yang mempunyai seperti kas (Mardiasmo, 1994)

Yang termasuk dalam kas menurut pengertian Akuntansi adalah alat pertukaran yang dapat diterima untuk pelunasan hutang dn bisa diterima sebagai suatu simpanan dalam bank atau tempat tempat lainnya yang dapat diambil sewaktu waktu. Kas terdiri dari uang kertas, uang logam, cek yang belum disetorkan, simpanan dalam bentuk giro atau bilyet.

Yang bukan merupakan kelompok kas adalah

1. Simpanan uang di Bank dalam bentuk asuransi berjangka

2. Setoran atau simpanan uang yang dibatasi penggunaannya

3. Uang tunai yang disimpan di dalam perusahaan yang dibatasi penggunaannya, misalnya untuk membayar deviden atau hutang

B. Arti Penting Analisa Sumber dan Penggunaan Kas

Analisa Sumber dan Penggunaan Kas atau sering disebut juga Analisa Aliran Kas merupakan salah satu alat analisa financial. Maksud utama dari analisa tersebut adalah untuk mengetahui bagaimana kas digunakan dan bagaimana kebutuhan kas tersebut dibelanjai. Dengan kata lain dengan analisa aliran kas itu akan dapat diketahui darimanakah kas berasal dan untuk apakah kas itu digunakan. Suatu laporan yang menggambarkan darimana kas berasal dan untuk apa itu digunakan maka disebut laporan sumber dan penggunaan kas.

Laporan Sumber dan Penggunaan Kas pada perusahaan sangat penting artinya bagi bank dalam menilai permintaan kredit yang diajukan kepadanya. Dengan mengadakan analisa terhadap laporan 
tersebut dapat diketahui bagaimana koperasi itu menggunakan kas yang dimilikinya. Sebagai langkah pertama dalam Analisa Sumber dan penggunaan kas adalah penyusunan Laporan Perubahan Neraca yang disusun atas dasar dua Neraca/ Laporan posisi keuangan dari dua saat atau waktu yang berbeda. Laporan Perubahan Neraca/ Laporan posisi keuangan tersebut menggambarkan peubahan dari masing masing elemen Neraca, yaitu antara dua titik waktu dan setiap perubahan elemen tersebut mencerminkan adanya sumber dan penggunaan kas. Dari laporan perubahan neraca tesebut dengan bantuan Laporan Laba ditahan dapatlah disusun Laporan Sumber dan Penggunaan Kas.

C. Pengertian Laporan Sumber dan Penggunaan Kas

Laporan Sumber dan Penggunaan Kas adalah laporan yang menunjukkan perubahan kas selama satu periode dan memberikan alasan mengenai perubahan kas selama satu periode dan memberikan alas an mengenai perubahan tersebut dengan menunjukkan darimana sumber dan penggunaannya ( Munawir, 2010). Adapun sumber penerimaan Kas dalam suatu perusahaan berasal dari :

1. Hasil penjualan investasi jangka panjang, aktiva tetap baik yang berwujud atau adanya penurunan aktiva tidak lancar yang diimbangi dengan penambahan kas.

2. Pengeluaran hutang surat tanda bukti baik jangka pendek maupun panjang (hutan obligasi, hutang hipotik, atau hutang jangka panjang lainnya) serta bertambahnya hutang yang diimbangi dengan penerimaan kas.

3. Penjualan atau adanya emisi saham maupun adanya penambahan modal oleh pemilik perusahaan dalam bentuk kas

4. Adanya penerimaan kas karena sewa,bunga atau deviden serta investasi sumbangan atau hadiah, maupun adanya pengembalian kelebihan pembayaran pajak pada periode sebelumnya.

Sedangkan penggunaan atau pengeluaran kas dapat disebabkan adanya transaksitransaksi sebagai berikut:

1. Pembelian saham atau obligasi sebagai investasi jangka pendek maupun jangka panjang serta adanya pembelian aktiva tetap lainnya.

2. Penarikan kembali saham yang beredar maupun adanya pengambilan kas perusahaan oleh pemilik perusahaan.

3. Pelunasan atau pembayaran angsuran hutang jangka pendek maupun jangka panjang, pembelian barang secara tunai, adanya biaya operasi yang meliputi upah, gaji, pembayaran supplies kantor, pembayaran sewa, bunga, premi asuransi dan advertensi.

4. Pengeluaran kas untuk deviden, pembayaran pajak, denda-denda lainnya. Aliran kas masuk dan aliran kas keluar akan terjadi secara terus menerus dalam perusahaan atau akan berlangsung terus selama hidupnya perusahaan. 
D. Laporan Keuangan

Dalam penyusunan Laporan Sumber
dan Penggunaan Kas data yang
diperlukan adalah:

1. Neraca

Neraca adalah laporan yang mengambarkan posisi keuangan perusahaan pada saat tertentu, unsurunsur dari neraca yang mempengaruhi perubahan jumlah kas adalah : (Al Haryono Yusup, 2004)

a. Aktiva lancar adalah aktiva perusahaan yang berupa kas atau aktiva lain yang diharapkan dapat dicairkan menjadi kas, dijual atau dipakai habis dalam satu tahun dalam siklus normal. Yang termasuk termasuk dalam Aktiva lancar adalah:

1). Kas dan Bank

2). Surat-surat berharga

3). Piutang

4). Persediaan

5). Persekot biaya

b. Aktiva tidak lancar adalah aktiva aktiva yang dimiliki oleh perusahaan, yang digunakan dalam jangka waktu lebih dari 1 tahun. Yang termasuk dalam aktiva tidak lancar adalah : investasi jangka panjang. Investasi jangka panjang dalam bentuk :

1) Saham, obligasi, surat surat berharga
2) Penyisihan dana untuk melunasi utang jangka panjang atau dana khusus lainnya

3) Aktiva lain misalnya pembelian tanah

c. Aktiva tetap

Yaitu harta perusahaan yang bersifat permanen dimana mempunyai umur ekonomis lebih dari satu tahun. Contohnya : Tanah, Bangunan, Peralatan, kendaraan, Mesin dan aktiva tetap lainnya

d. Hutang lancar

Yaitu hutang perusahaan yang diharapkan dapat dilunasi dalam jangka waktu paling lama 1 periode akuntansi, dengan menggunakan sumber sumber yang merupakan aktiva lancar dengan menimbulkan utang lancar yng lain. Yang termasuk hutang lancar adalah :

1) Hutang usaha

2) Hutang biaya

3) Hutang pendapatan.

4) Hutang bank

e. Hutang Jangka Panjang

Adalah kewajiban perusahaan yang jangka waktu pelunasannya lebih dari 1 tahun. Yang termasuk hutang jangka panjang adalah :

1) Hutang obligasi

2) Hutang hipotik

3) Hutang lain lain

- Yang termasuk hutang lain lain adalah : 
- Pendapatan yang ditangguhkan

- Uang muka jaminan

- Hutang kepada direksi

f. Modal

1) Modal saham Yaitu jumlah nominal saham yang beredar

2) Laba ditahan Merupakan laba yang diperoleh perusahaan tiap tiap periode

3) Agio saham Yaitu kelebihan nilai jual saham atas nilai nominalnya

\section{Laporan Laba Rugi}

Adalah laporan yang menggambarkan keadaan perusahaan selama satu periode tertentu. Pos pos yang terdapat dalam laporan Laba Rugi pada dasarnya dibagi 3 hal yaitu :

a. Pendapatan

Adalah pertambahan modal pemilik perusahaan biasanya berupa penerimaan aktiva dari pihak lain sebagai akibat dari penyerahan barang atau jasa ke perusahaan kepada pihak lain.

b. Biaya

Adalah pengurangan modal pemilik perusahaan dalam perusahaan biasanya berupa pemakaian atau penyerahan atribut dari penerimaan barang atau jasa oleh perusahaan lain

c. Laba rugi

Adalah hasil bersih operasi perusahaan dari pendapatan dikurangi biaya

1) untuk mencatat penurunan aktiva, kenaikan hutang, dan modal serta pertambahan pendapatan dan berkurangnya biaya
2) Menganalisa perubahan perubahan yang terjadi pada pos pos neraca dan pos pos Laba rugi untuk menentukan adanya perubahan yang tidak mempengaruhi kas

3) Membuat jurnal penyesuaian dalam worksheet tersebut untuk menghilangkan akibat pengaruh transaksi non kas yang sudah dicatat dalam periode tersebut

4) Memindahkan saldo atau perubahan perubahan setelah disesuaikan kedalam kolom " kenaikan dan penurunan kas ", penurunan aktiva, kenaikan hutang, modal dan kenaikan biaya merupakan penggunaan kas

\section{E. METODE ANALISIS DATA}

1. Membandingkan 2 laporan keuangan untuk mengetahui perubahan masing masing elemen laporan keuangan

2. Mengelompokkan perubahan perubahan tersebut dalam golongan yang memperbesar kas dan golongan yang memperkecil kas

3. Menganalisa darimana sumber kas berasal dan untuk apa penggunaan kas

4. Menyusun Laporan Sumber dan Penggunaan Kas

\section{HASIL PENELITIAN DAN PEMBAHASAN}

Data yang diperoleh sehubungan dengan permasalahan yang dibahas, adalah

1. Neraca tahun 2012 - 2013 (Tabel I dan Tabel II) 
Tabel I

\section{NERACA TAHUN 2012}

Per 31 Desember 2012

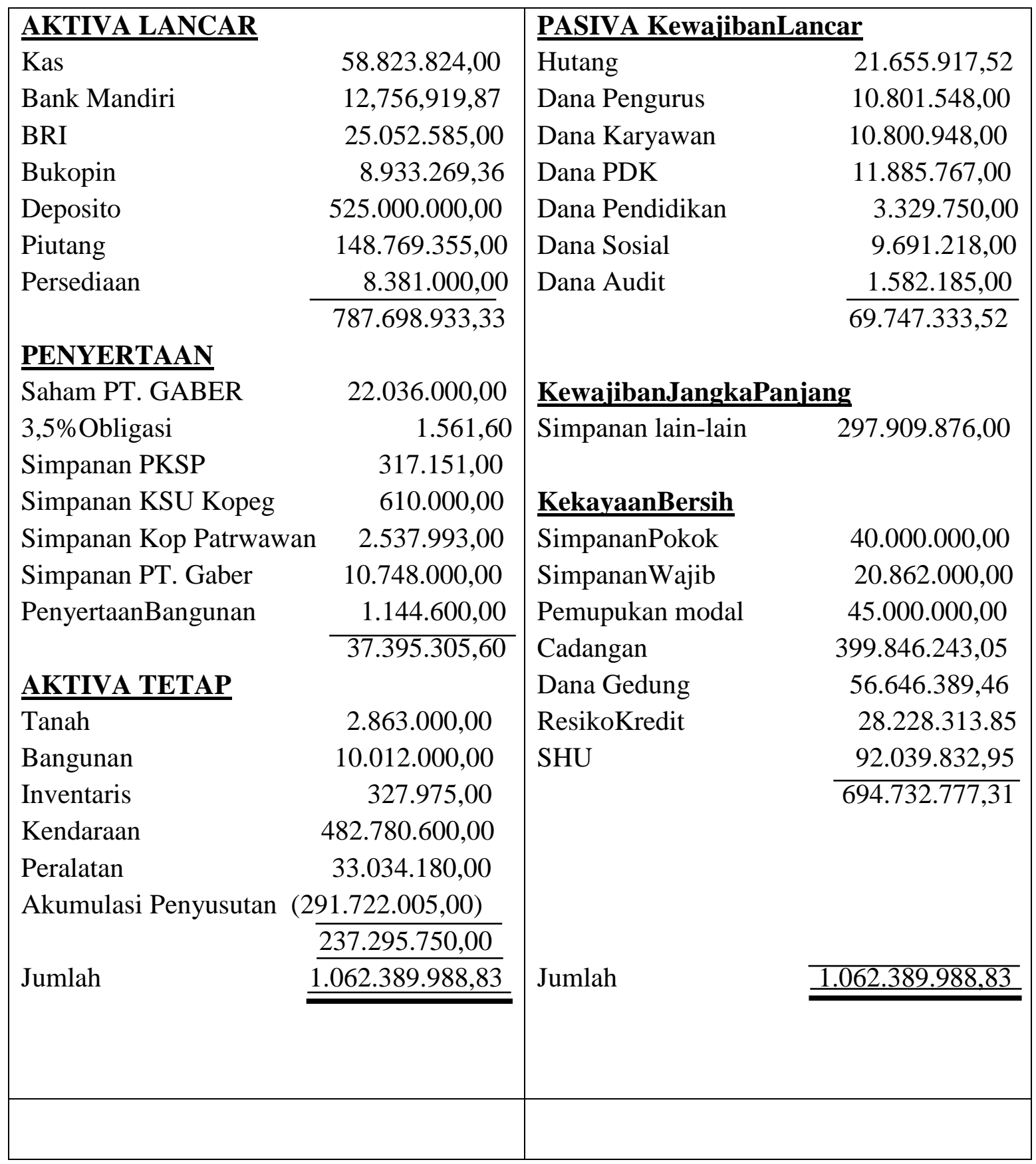


Tabel II

NERACA TAHUN 2013

Per 31 Desember 2013

\begin{tabular}{|c|c|c|c|}
\hline \multicolumn{2}{|l|}{ AKTIVA LANCAR } & \multicolumn{2}{|c|}{ PASIVA KewajibanLancar } \\
\hline Kas & $5.723 .000,00$ & Hutang & $20.805 .854,52$ \\
\hline Bank Mandiri & $78.969 .658,01$ & Dana Pengurus & $7.000 .792,00$ \\
\hline BRI & 21.102.731,00 & Dana Karyawan & $7.000 .233,00$ \\
\hline Bukopin & $2.623 .577,32$ & Dana PDK & $6.457 .340,00$ \\
\hline Deposito & $250.000 .000,00$ & Dana Pendidikan & $2.279 .729,00$ \\
\hline Piutang & $181.684 .085,00$ & Dana Sosial & $5.700 .791,00$ \\
\hline \multirow[t]{2}{*}{ Persediaan } & $1.798 .500,00$ & Dana Audit & $572.709,00$ \\
\hline & $541.901 .551,33$ & & $50.267 .448,52$ \\
\hline \multicolumn{4}{|l|}{ PENYERTAAN } \\
\hline Saham PT. GABER & $16.800 .000,00$ & \multicolumn{2}{|c|}{ KewajibanJangkaPanjang } \\
\hline 3,5 Obligasi & $1.561,60$ & \multicolumn{2}{|c|}{ Simpanan lain-lain $\quad 209.505 .521,00$} \\
\hline Simpanan PKSP & $317.151,00$ & & \\
\hline Simpanan KSU Kopegt & $610.000,00$ & \multicolumn{2}{|l|}{$\underline{\text { KekayaanBersih }}$} \\
\hline Simpanan Kop Patrwawan & $2.177 .992,83$ & SimpananPokok & $40.000 .000,00$ \\
\hline Simpanan PT. Gaber & $7.841 .000,00$ & SimpananWajib & $20.862 .000,00$ \\
\hline \multirow[t]{2}{*}{ PenyertaanBangunan } & $1.144 .600,00$ & Pemupukan modal & $30.500 .000,00$ \\
\hline & $28.892 .305,43$ & Cadangan & $323.846 .813,44$ \\
\hline AKTIVA TETAP & & Dana Gedung & $49.166 .389,46$ \\
\hline Tanah & $2.863 .000,00$ & ResikoKredit & 28.228 .313 .85 \\
\hline Bangunan & $8.012 .000,00$ & SHU & $72.947 .545,49$ \\
\hline Inventaris & $327.975,00$ & & $5 \overline{65.611 .082,24}$ \\
\hline Kendaraan & $446.980 .600,00$ & & \\
\hline Peralatan & $16.901 .680,00$ & & \\
\hline \multirow[t]{2}{*}{ Akumulasi Penyusutan } & $(20.540 .060,00)$ & & \\
\hline & $254.590 .195,00$ & & \\
\hline Jumlah & $825.384 .051,76$ & Jumlah & $825.384 .051,76$ \\
\hline
\end{tabular}


Tabel III

\section{Laporan Rugi Laba}

Per 31 Desember 2013

\section{Pendapatan dan Penjualan}

- Pendapatan bunga bank

$39.562 .767,76$

- Penjualan minyak tanah

4.173.156.800,00

- Penjualan beras $306.814 .960,00$

- Penjualan gula pasir

$39.856 .370,00$

- Pendapatan photo copy

$333.965 .000,00$

- Angkut minyak tanah

$370.750,00$

- Pendapatan lain-lain

2.081.590,00

- Wartel

$450.850,00$

\section{Jumlah}

4.896.299.987,76

\section{$\underline{\text { Harga Pokok Penjualan }}$}

- Stock awal

1.798.500,00

- Pembelian :

1. Minyak tanah

3.844.186.310,00

2. Beras

$109.684 .800,00$

3. Gula pasir

$\underline{238.384 .600,00}$

- Barang siap jual

4.192.255.710,00

- Stock akhir

4.192.255.710,00

$8.381 .000,00$

Harga Pokok Penjualan

4.185.673.190,00

Pendapatan Bruto

710.585.897,76

$\underline{\text { Biaya }}$

- Bahan Pengemas

- Promosi iklan reklame

- Gaji pegawai

- Perjalanan dinas

$51.650,00$
$200.000,00$
$293.494 .400,00$
$7.030 .000,00$
22.766 .000 .00
$21.844 .550,00$
$3.538 .035,00$
$10.545 .279,81$
$1.363 .250,00$

JURNAL AKUNTANSI DAN PAJAK VOL. 16 NO. 01, JULI 2015 - 74 
- Pakaian kerja

- Pengganti biaya pengobatan

- Gaji pengurus

- Honor pengawas

- Rapat

- Pesangon jasa purna tugas

- Jamsostek

- Alat tulis dan cetakan

- Komunikasi

- Perawatan inventaris

- Lain-lain

- BBM dan pelumas

- Service kendaraan

- Sukucadang

- Asuransi, izin,PKB

- THR

- THR anggota

- Biaya penyusutan

Jumlah

\section{Laba bersih}

$3.530 .250,00$

$3.000 .180,00$

$32.938 .360,00$

7.610.000,00

$5.500 .000,00$

$90.256 .250,00$

$9.687 .545,00$

$5.859 .510,00$

2.911.347,00

1.116.600,00

$63.518 .644,00$

$67.906 .500,00$

$30.938 .075,00$

4.992.050,00

$8.401 .500,00$

$13.024 .764,00$

$9.120 .000,00$

87.399.290,00

\section{PEMBAHASAN MASALAH}

Untuk memecahkan masalah dalam "Analisa Sumber dan Penggunaan Kas" maka langkah-langkah yang diperlukan :

1. Melakukan perbandingan Neraca antara 2 periode kemudian mengelompokkan perubahan-perubahan yang terjadi akan memperbesar jumlah kas dan perubah yang memperkecil jumlah kas dalam hal ini perbandingan antara tahun 2012 dengan tahun 2013

2. Mengadakan konsolidasi dari semua informasi, jika telah mengelompokkan perubahan-perubahan yang terjadi pada neraca yang diperbandingkan.

\section{$\underline{618.546 .061,81}$}

\subsubsection{2,95}

3. Menarik kesimpulan yang diperoleh dari hasil Analisa perubahan dalam Neraca dari Laporan Sumber Penggunaan Kas Berikut ini disusun worksheet Laporan Sumber dan Penggunaan Kas (table IV.) 
Analisis Laporan Sumber Dan Penggunaan Kas Pada KUD Tani

KUD Tani Makmur Tawangmangu

Worksheet Sumber Penggunaan Kas

Tahun yang terakhir 31 Desember 2013

\begin{tabular}{|c|c|c|c|c|c|c|}
\hline \multirow{2}{*}{ PERKIRAAN } & \multirow{2}{*}{ TAHUN 2012} & \multirow{2}{*}{ TAHUN 2013} & \multicolumn{2}{|c|}{ PERUBAHAN } & \multicolumn{2}{|c|}{ SUMBER } \\
\hline & & & D & $\mathrm{K}$ & SUMBER & PENGGUNAAN \\
\hline AKTIVA LANCAR & & & & \multirow{6}{*}{$66.212 .738,14$} & \multirow{6}{*}{$66.212 .738,14$} & \\
\hline Kas & 5.723 .000 & $58.823 .824,00$ & $53.109 .824,00$ & & & \\
\hline Bank Mandiri & $78.969 .658,01$ & $12.756 .919,00$ & & & & \\
\hline BRI & $21.102 .731,00$ & $25.052 .585,00$ & $3.922 .854,00$ & & & $3.922 .854,00$ \\
\hline Bukopin & $2.623 .577,32$ & $8.933 .269,36$ & $6.309 .692,04$ & & & $6.309 .692,04$ \\
\hline Deposito & $250.000 .000,00$ & $525.000 .000,00$ & $275.000 .000,00$ & & & $275.000 .000,00$ \\
\hline Piutang & $181.684 .085,00$ & $148.769 .355,00$ & & \multirow[t]{2}{*}{$32.914 .750,00$} & \multirow[t]{2}{*}{$32.914 .750,00$} & \\
\hline Persediaan & $1.798 .500,00$ & $8.381 .000,00$ & $6.582 .500,00$ & & & $6.582 .500,00$ \\
\hline Jumlah Aktiva Lacar & $541.901 .551,33$ & $787.698 .933,33$ & & & & \\
\hline \multicolumn{7}{|l|}{ INVES JANGKA PANJANG } \\
\hline Saham PT. GAPERTA & $16.800 .000,00$ & $22.036 .000,00$ & \multirow[t]{4}{*}{$5.236 .000,00$} & & & \multirow[t]{4}{*}{$5.236 .000,00$} \\
\hline 3,5 obigasi & $1.561,00$ & $1.561,60$ & & & & \\
\hline Simpanan PKSP & $317.151,00$ & $317.151,00$ & & & & \\
\hline Simpanan KSU Kopegti & $610.000,00$ & $610.000,00$ & & & & \\
\hline Simpanan KOP Patrawan & $2.177 .992,83$ & $2.537 .993,00$ & \multirow{3}{*}{$\begin{array}{r}360.000,17 \\
2.907 .000,00\end{array}$} & & & $360.000,17$ \\
\hline Simpanan PT. Gapertama & $7.841 .000,00$ & $10.748 .000,00$ & & & & $2.907 .000,00$ \\
\hline Penyertaan Bangunaan & $1.144 .600,00$ & $1.144 .600,00$ & & & & \\
\hline Jumlah Investasi Jangka Panjang & $28.892 .305,43$ & $37.395 .305,60$ & & & & \\
\hline \multicolumn{7}{|l|}{ AKTIVA TETAP } \\
\hline Tanah & $2.863 .000,00$ & $2.863 .000,00$ & & \multirow{5}{*}{$45.000,00$} & \multirow{5}{*}{$45.000,00$} & \\
\hline Bangunan & $8.012 .000,00$ & $10.012 .000,00$ & $2.000 .000,00$ & & & $2.000 .000,00$ \\
\hline Inventaris & $327.975,00$ & $327.975,00$ & & & & \\
\hline Kendaraan & $446.980 .600,00$ & $482.780 .600,00$ & $35.800 .000,00$ & & & $35.800 .000,00$ \\
\hline Peralatan & $16.901 .680,00$ & $33.034 .180,00$ & $16.132 .500,00$ & & & $16.132 .500,00$ \\
\hline
\end{tabular}

JURNAL AKUNTANSI DAN PAJAK VOL. 16 NO. 01, JULI 2015 - 76 
Analisis Laporan Sumber Dan Penggunaan Kas Pada KUD Tani

\begin{tabular}{|l|r|r|r|r|r|}
\hline Akumulasi Penyusutan & $20.540 .060,00$ & $291.722 .005,00$ & & $71.181 .945,00$ & $71.181 .945,00$ \\
\hline Jumlah Aktiva Tetap & $254.590 .195,00$ & $237.295 .750,00$ & & & \\
\hline TOTAL AKTIVA & $825.384 .051,76$ & $1.062 .389 .988,83$ & & & \\
\hline
\end{tabular}

\begin{tabular}{|c|c|c|c|c|c|c|}
\hline \multirow{2}{*}{ PERKIRAAN } & \multirow{2}{*}{ TAHUN 2012} & \multirow{2}{*}{ TAHUN 2013} & \multicolumn{2}{|c|}{ PERUBAHAN } & \multicolumn{2}{|c|}{ SUMBER } \\
\hline & & & D & K & SUMBER & PENGGUNAAN \\
\hline \multicolumn{7}{|l|}{ KEWAJIBAN LANCAR } \\
\hline Hutang & $20.805 .854,52$ & $21.655 .917,52$ & & $850.063,00$ & $850.063,00$ & \\
\hline Dana Pengurus & 7.000.792,00 & $10.801 .548,00$ & & $3.800 .756,00$ & $3.800 .756,00$ & \\
\hline Dana Karyawan & $7.000 .233,00$ & $10.800 .948,00$ & & $3.800 .715,00$ & $3.800 .715,00$ & \\
\hline Dana PDK & $6.457 .340,00$ & $11.885 .767,00$ & & $5.428 .427,00$ & $5.428 .427,00$ & \\
\hline Dana Pendidikan & $2.279 .729,00$ & $3.329 .750,00$ & & $600.021,00$ & $600.021,00$ & \\
\hline Dana Sosial & $5.700 .791,00$ & $9.691 .218,00$ & & $30.990 .427,00$ & $30.990 .427,00$ & \\
\hline Dana Audit & $572.709,00$ & $1.582 .185,00$ & & $1.009 .476,00$ & $1.009 .476,00$ & \\
\hline Jumlah Kewajiban Lancar & $50.267 .448,52$ & $69.747 .333,52$ & & & & \\
\hline \multicolumn{7}{|l|}{ KEWAJIBAN JANGKA PANJANG } \\
\hline Simpanan Lain-lain & $209.505 .521,00$ & $297.909 .876,00$ & & $88.404 .355,00$ & $88.404 .355,00$ & \\
\hline Jumlah Kewajiban Jangka Panjang & $209.505 .521,00$ & $297.909 .876,00$ & & & & \\
\hline \multicolumn{7}{|l|}{$\underline{\text { KEKAYAAN BERSIH }}$} \\
\hline Simpanan Pokok & $40.000 .000,00$ & $40.000 .000,00$ & & & & \\
\hline Simpanan Wajib & $20.862 .000,00$ & $20.862 .000,00$ & & & & \\
\hline Pemupukan Modal & $30.500 .000,00$ & $45.000 .000,00$ & & $14.500 .000,00$ & $14.500 .000,00$ & \\
\hline Cadangan & $323.846 .813,44$ & $399.846 .243,05$ & & 75.999.429,61 & $75.999 .429,61$ & \\
\hline Dana Gedung & $49.166 .389,46$ & $56.646 .389,46$ & & $7.530 .000,00$ & $7.530 .000,00$ & \\
\hline Resiko Kredit & 28.228 .313 .85 & 28.228.313.85 & & $12.000 .000,00$ & $12.000 .000,00$ & \\
\hline SHU & $72.947 .545,49$ & $92.039 .832,95$ & & 19.092.267,46 & $19.092 .267,46$ & \\
\hline Jumlah Kekayaan Bersih & $565.611 .082,24$ & 694.732.777,31 & & & & \\
\hline TOTAL PASIVA & $825.384 .051,76$ & $1.062 .389 .988,83$ & $407.360 .370,20$ & $407.360 .370,20$ & $407.360 .370,20$ & $354.250 .546,02$ \\
\hline \multicolumn{5}{|l|}{ Kenaikan kas tahun 2013} & & $53.109 .824,00$ \\
\hline & & & & & $407.360 .370,02$ & $407.360 .370,02$ \\
\hline
\end{tabular}




\section{KUD Tani Makmur}

Laporan Sumber dan Penggunaan Kas

Periode yang berakhir 31 Desember 2013

\section{SumberKas}

- Berkurangnya Bank Mandiri

$66.212 .738,14$

- Berkurangnya Piutang

$32.914 .750,00$

- Berkurangnya Inventaris

$45.000,00$

- Berkurangnya akumulasi penyusutan

$71.181 .945,00$

- Berkurangnya hutang

$850.063,00$

- Berkurangnya dana pengurus

$3.800 .576,00$

- Berkurangnya dana karyawan

$3.800 .715,00$

- Berkurangnya dana PDK

$5.428 .427,00$

- Berkurangnya pendidikan

$600.021,00$

- Berkurangnya social

$3.990 .427,00$

- Berkurangnya audit

$1.009 .476,00$

- Berkurangnya simpanan lain-lain

$88.406 .355,00$

- Berkurangnya modal

$14.500 .000,00$

- Berkurangnya cadangan

$75.999 .429,00$

- Berkurangnya dana gedung

$7.530 .000,00$

- Berkurangnya resiko kredit

$12.000 .000,00$

- Bertambahnya SHU

$\frac{19.092 .267,46}{407.360 .370,20}$

\section{Penggunaan Kas}

- Bertambahnya BRI

$3.922 .854,00$

- Bertambahnya Bukopin

$6.309 .692,00$

- Bertambahnya Deposito

$275.000 .000,00$

- Bertambahnya persediaan

$6.582 .500,00$

- Bertambahnya saham PT. Gaber

$5.236 .000,00$

$360.000,17$

2.907.000,00

- Bertambahnya PT. Gaber

$2.000 .000,00$

- Bertambahnya bangunan

$35.800 .000,00$

- Bertambahnya kendaraan

$16.132 .500,00$

- Bertambahnya peralatan

$354.250 .546,20$

$53.109 .824,00$

Kenaikan kas tahun 2013

$407.360 .370,20$

JURNAL AKUNTANSI DAN PAJAK VOL. 16 NO. 01, JULI 2015 - 78 
Keterangan :

Sumber Kas tahun 2013

1. Berkurangnya simpanan kas Bank Mandiri Rp. 66.212.738,14 berarti terjadi Pengambilan Kas di Bank dan Kas di Koperasi bertambah

2. Berkurangna piutang sebesar Rp. 32.914.750,00 berarti terjadi pelunasan piutang dari anggota,kas bertambah

3. Bertambahnya akumulasi penyusutan sebesar Rp. 71.181.945,00 berarti ada dana yang disisihkan untuk pembelian aktiva tetap dan sementara dana tersebut belum digunakan, menjadi sumber kas bagi koperasi

4. Bertambahnya simpanan-simpanan lain sebesar Rp. 88.404.355,00 (kewajiban jangka panjang) berarti terdapat dana yang berasal dari simpanan lain-lain (sumber kas)

5. Bertambahnya cadangan sebesar Rp.75.999.429,61 berarti terdapat SHU yang disisihkan atau dicadangkan untuk keperluan tertentu (kas bertambah)

6. Bertambahnya resiko kredit sebesar Rp. 12.000.000 berarti terdapat dana yang dicadangkan untuk resiko kredit (sumber kas)

7. Berkurangnya inventaris sebesar Rp. 45.000,00 berarti terdapat penjualan inventaris (kas bertambah)

8. Bertambahnya hutang sebesar Rp. 850.063,00 berarti terdapat tambahan kas yang berasal dari hutang (kas bertambah)

9. Bertambahnya dana pengurus $\mathrm{Rp}$. 3.800.756,00 berarti terdapat tambahan dana yang berasal dari dana pengurus
Bertambahnya dana karyawan Rp. 3.800.715,00 berarti terdapat tambahan dana yang berasal dari dana karyawan

10. Bertambahnya dana karyawan $\mathrm{Rp}$. 3.800.715,00 berarti terdapat tambahan dana yang berasal dari dana karyawan

11. Bertambahnya dana PDK sebesar Rp. 5.428.427,00 berarti terdapat tambahan dana yang berasal dari dana PDK

12. Bertambahnya dana pendidikan sebesar Rp. 600.021,00 berarti terdapat dana tambahan yang berasal dari pendidikan

13. Bertambahnya dana social sebesar $\mathrm{Rp}$. 3.990.427,00 berarti terdapat dana tambahan yang berasal dari dana sosial

14. Bertambahnya dana audit sebesar $\mathrm{Rp}$. 1.099.476,00 berarti terdapat dana tambahan yang berasal dari dana audit

15. Bertambahnya pemupukan modal sebesar Rp. 14.500.000,00 berarti terdapat tambahan dana yang berasal dari tambahan modal

16. Bertambahnya dana gedung sebesar Rp. 7.530.000,00 berarti terdapat dana tambahan yang berasal dari dana gedung.

17. Bertambahnya SHU sebesar Rp. 19.092.267.46 berarti terdapat tambahan dana yang berasal dari bertambahnya SHU

Penggunaan kas tahun 2013 ::

1. Bertambahnya deposito sebesar Rp. 275.000.000,00 berarti terdapat dana yang digunakan untuk disimpan di deposito 
2. Bertambahnya Bukopin sebesar Rp. 6.309.692,04 berarti terdapat dana yang digunakan untuk disimpan di Bukopin

3. Bertambahnya persediaan sebesar $\mathrm{Rp}$. 6.582.500,00 berarti terdapat dana yang digunakan untuk pembelian persediaan

4. Bertambahnya kendaraan sebesar Rp. 35.800.000,00 berarti terdapat dana yang digunakan untuk pembelian kendaraan

5. Bertambahnya peralatan sebesar $\mathrm{Rp}$. 16.132.500,00 berarti terdapat dana yang digunakan untuk pembelian peralatan

6. Bertambahnya BRI sebesar Rp. 3.992.854,00 berarti terdapat dana yang digunakan untuk disimpan di BRI

7. Bertambahnya saham PT. GABER sebesar Rp. 5.236.000,00 berarti terdapat dana yang digunakan untuk pembelian saham

8. Bertambahnya simpanan Kop. Patrawan sebesarRp. 360.000,17 berarti terdapat dana yang disimpan di Kop. Patrawan

9. Bertambahnya simpanan PT. Gaber sebesar Rp. 2.907.000,00 berarti terdapat dana yang disimpan di PT.Gaber

10. Bertambahnya bangunan sebesarRp. 2.000.000,00 berarti terdapat dana yang digunakan untuk pembelian bangunan

\section{KESIMPULAN}

Dari pembahasan tentang Analisa Sumber dan Penggunaan Kas dapat ditarik kesimpulan bahwa :

1. Sumber kas terbesar tahun 2013 berasal dari bertambahnya kewajiban jangka panjang yaitu berupa simpanan lain-lain sebesarRp. 88.404.355,00
2. Penggunaan kas terbesar tahun 2013 digunakan untuk penyimpanan dana dalam bentuk Deposito sebesar Rp. 275.000.00,00

3. Pada periode tahun 2013 terjadi kenaikan kas sebesar Rp. 53.109.824 hal ini disebabkan karena pada tahun 2013 sumber kas sebesarRp. 407.360.370,2 lebih besar dari penggunaan kas Rp.354.250.546,02.

Adapun kenaikan kas tahun 2013 di koperasi berarti bahwa KUD Tani Makmur telah melaksanakan fungsi dan tujuannya dengan sebaik-baiknya untuk mewujudkan kesejahteraan pada anggota khususnya dan masyarakat pada umumnya, dan dapat menciptakan kemakmuran secara bersama-sama ini akan menambah kepercayaan pada masyarakat tentang Arti Pentingnya Perkoperasian.

\section{DAFTAR PUSTAKA}

Agnes Sawit, 2005, Analisa Kinerja Keuanagn dan Perencanaan Keuangan Perusahaan, PT

Gramedia Pustaka Utama, Jakarta

Ahmad Rodoni dan Herni Ali,2010, Manajemen Keuangan, Mitrawacana Media, Jakarta

Al Haryono Yusup, 2005, Akuntansi Keuangan Dasar, Jilid 1, edisi 7, STIE YKPN, Yogyakarta

Bambang Riyanto, 2001, Dasar Dasar Pembelanjaan Perusahaan, Edisi 7, BPFE, Yogyakarta 
Helfert, Erich A, 2006, Teknik analisa Keuangan, edisi 10, penerbit Erlangga, Jakarta

Irham Fahmi, 2001, Analisa Laporan Keuangan, AUFABETA, Bandung

J Supranto, 1991, Metode Riset, Lembaga Penerbit FE UI, Jakarta

Kieso Donald E, Yeeny, 2000, Akuntansi Intermediate, Edisi 12, jilid 1, Erlangga, Jakarta

Mulyadi dan Jonny Setyawan, 2004, Sistem Perencanaan dan Pengendalian Manajemen, UGM, Yogyakarta

Munawir, 2010, Analisa Laporan Keuangan, Penerbit Liberty, Yogyakarta

Sutrisno, 2005, Teori Akuntansi Perekayasaan Pelaporan Keuangan, Edisi ketiga, BPFE, Yogyakarta

Syafaruddin Alwi, 1994, Alat alat analisis dalam pembelanjaan, edisi revisi, Andi Offset, Yogyakarta

Sugiri, 1987, Pengantar Akuntansi II, Yayasan Penerbit FE, Yogyakarta

Supranto, Metodologi Riset, Aplikasi Dalam Pemasaran, edisi 5, Penerbit FE UI, Jakarta

Toto Pribadi, 2008, Analisa Ratio Keuangan, Penerbit PPM, Jakarta
Wild Subromayan, 2010, Analisa Laporan Keuangan, Salemba Empat, Jakarta

Zaki Baridwan, 2004, Akuntansi Keuangan, Edisi 8, BPFE, Yogyakarta 